\title{
Heterologous expression of a Streptomyces cyaneus laccase for biomass modification applications
}

\author{
Selin Ece ${ }^{1}$, Camilla Lambertz ${ }^{1}$, Rainer Fischer ${ }^{1,2}$ and Ulrich Commandeur ${ }^{1 *}$
}

\begin{abstract}
Laccases are used for the conversion of biomass into fermentable sugars but it is difficult to produce high yields of active laccases in heterologous expression systems. We overcame this challenge by expressing Streptomyces cyaneus CECT 3335 laccase in Escherichia coli (SCLac) and we achieved a yield of up to $104 \mathrm{mg} \mathrm{L}^{-1}$ following purification by one-step affinity chromatography. Stability and activity assays using simple lignin model substrates showed that the purified enzyme preparation was active over a broad pH range and at high temperatures, suggesting it would be suitable for biomass degradation. The reusability of ScLac was also demonstrated by immobilizing the enzyme on agarose beads with a binding yield of 33\%, and by the synthesis of cross-linked enzyme aggregates with an initial activity recovery of $72 \%$.
\end{abstract}

Keywords: Laccase, Streptomyces cyaneus, Heterologous expression, Enzyme immobilization, Lignocellulose modification

\section{Introduction}

Laccases are the largest subgroup of the multi-copper oxidase protein superfamily (Ihssen et al. 2015). They can oxidize a broad range of substrates including phenolic compounds, azo dyes, aromatic amines, non-phenolic substrates (mostly with the help of mediators), anilines and aromatic thiols, and recalcitrant environmental pollutants (Canas and Camarero 2010; Majumdar et al. 2014; Margot et al. 2013; Widsten and Kandelbauer 2008). Each monomeric laccase contains four copper atoms located at three different positions, namely the type 1 (T1), type 2 (T2) and binuclear type 3 (T3) copper sites, all of which are involved in the oxidation of substrate molecules accompanied by the reduction of molecular oxygen to two molecules of water (Thurston 1994). The copper atoms bind histidine residues that are conserved among the laccases of different organisms (Claus 2003; Luis et al. 2004). The T1 copper gives the laccase its

\footnotetext{
*Correspondence: Ulrich.Commandeur@molbiotech.rwth-aachen.de 1 Institute for Molecular Biotechnology (Biology VII), RWTH Aachen University, Worringerweg 1, 52074 Aachen, Germany

Full list of author information is available at the end of the article
}

blue color and is also responsible for the final oxidation of the substrate. Electrons are transferred from the T1 copper site to the T2/T3 sites, where molecular oxygen is reduced to water. The T1 copper is characterized by its absorbance at $610 \mathrm{~nm}$ whereas the T3 copper shows weak absorbance at $330 \mathrm{~nm}$. The T2 copper is colorless but it can be detected by electro-paramagnetic resonance spectroscopy (EPR) (Gunne et al. 2013; Thurston 1994).

Laccases are used in many biotechnological processes in the paper and pulp, textile, pharmaceutical and petrochemical industries, and also for the bioremediation of industrial wastes (Chandra and Chowdhary 2015; Morozova et al. 2007; Munk et al. 2015; Rodriguez Couto and Toca Herrera 2006; Roth and Spiess 2015). Laccases can also be combined with laccase mediator systems (LMS) such as 1-hydroxybenzotriazole (HBT) for the pretreatment and depolymerization of lignocellulosic biomass (Call and Mücke 1997). The digestibility of cellulose can be increased following lignin decomposition by laccases (Chen et al. 2012). In the presence of HBT, lignin can also be removed from whole woody and nonwoody feedstocks to increase sugar and ethanol yields (Gutierrez et al. 2012), whereas the alternative mediator 
2,2'-azino-bis (3-ethylbenzothiazoline-6-sulfonic acid) (ABTS) can allow an alkaline-stable laccase to selectively degrade lignin within lignocellulose and improve the enzymatic hydrolysis of wheat straw when combined with a steam explosion pretreatment (Qiu and Chen 2012).

Although laccases are ubiquitous, research has focused mainly on fungal laccases because many different isozymes have been identified, particularly among the white-rot fungi. Following the identification of the first bacterial laccase (Givaudan et al. 1993) many further examples were discovered (Chandra and Chowdhary 2015). The properties of bacterial laccases, such as their enantioselectivity and stability at high $\mathrm{pH}$ and high temperatures, are not yet understood in detail, but they have many advantages for applications such as the pretreatment of recalcitrant biomass. The large-scale production of fungal laccases is challenging because of the slow growth rates of fungi. They also have a narrower optimal $\mathrm{pH}$ range. These factors have made bacterial laccases a valuable alternative (Ausec et al. 2011; Bugg et al. 2011; Chandra and Chowdhary 2015).

Here we describe the heterologous expression of a laccase from Streptomyces cyaneus CECT 3335 in Escherichia coli ( $S c \mathrm{Lac}$ ). After purification, the recombinant enzyme preparation was characterized and compared in terms of its activity against common substrates. Two immobilization methods were used to assess the reusability of the recombinant laccase, thus offering a way to reduce the costs of enzyme production.

\section{Materials and methods Cloning}

The laccase coding sequence (GenBank HQ857207) was codon optimized for expression in E. coli (European Nucleotide Archive LT795002), synthesized by Genscript (Piscataway, USA) and transferred to the expression vector pET-22b $(+)$ (Novagen, Darmstadt, Germany). The gene was inserted at the NdeI and XhoI sites using forward primer $5^{\prime}$-GGA ATT CCA TAT GGA AAC CGA TAT TAT TGA ACG CC-3' and reverse primer 5'-AAG CTC GAG GCC GGT ATG GCC CGC GCC ATG-3'. A $\mathrm{His}_{6}$ tag was added to the C-terminus to enable protein purification by immobilized metal affinity chromatography (IMAC). E. coli BL21 (DE3) Star (Novagen, Merck KGaA, Darmstadt, Germany) was used as the expression host.

\section{Expression and protein extraction}

Transformed E. coli BL21 (DE3) Star cells were incubated overnight at $37{ }^{\circ} \mathrm{C}$ shaking at $180 \mathrm{rpm}$ in $50 \mathrm{~mL}$ lysogeny broth (LB) containing $100 \mu \mathrm{g} \mathrm{mL}{ }^{-1}$ ampicillin. The overnight culture was then used to inoculate $500 \mathrm{~mL}$ terrific broth (TB) supplemented with the same antibiotics, and the culture was incubated as described above until the optical density $\left(\mathrm{OD}_{600}\right)$ reached 0.6. Laccase expression was then induced by adding $0.04 \mathrm{mM}$ isopropyl $\beta$-D-1-thiogalactopyranoside (IPTG). Furthermore, $10 \mathrm{mM}$ benzyl alcohol was added to the culture 20 min before the IPTG to induce the expression of native chaperones (de Marco et al. 2005). The laccase culture was incubated at $20^{\circ} \mathrm{C}$ for $20 \mathrm{~h}$ at $180 \mathrm{rpm}$ and the cells were harvested by centrifugation $(5000 \times g$, $\left.15 \mathrm{~min}, 4{ }^{\circ} \mathrm{C}\right)$. The cell pellet was resuspended in $20 \mathrm{mM}$ potassium phosphate buffer ( $\mathrm{pH}$ 7.4) containing $20 \mathrm{mM}$ imidazole and $300 \mathrm{mM} \mathrm{NaCl}$. The cells were disrupted by sonication in the presence of $0.5 \mathrm{mM}$ phenylmethylsulfonyl fluoride, $1 \mathrm{mg} \mathrm{mL} \mathrm{m}^{-1}$ lysozyme and $10 \mu \mathrm{g} \mathrm{mL}^{-1}$ DNase I. The cell suspension was then centrifuged $\left(30,000 \times g, 30 \mathrm{~min}, 4^{\circ} \mathrm{C}\right)$ and the supernatant was separated from the cell debris by passing through a $0.45-\mu \mathrm{m}$ filter.

\section{Purification}

ScLac was purified by IMAC using $5 \mathrm{~mL}$ HiTrap Chelating Sepharose FF (GE Healthcare, Freiburg, Germany). The cell extract was applied to the column at a flow rate of $3 \mathrm{~mL} \mathrm{~min}{ }^{-1}$ in potassium phosphate running buffer (pH 7.4) containing $20 \mathrm{mM}$ imidazole and $300 \mathrm{mM} \mathrm{NaCl}$ (also used as the washing buffer). Bound proteins were eluted by using a gradient of imidazole $(0-500 \mathrm{mM})$ with a total volume of $50 \mathrm{~mL}$. Elution fractions $(2 \mathrm{~mL})$ were checked by sodium dodecyl sulfate polyacrylamide gel electrophoresis (SDS-PAGE) using 5-12\% Tris-glycine gels (Laemmli 1970). The gels were stained with Coomassie Brilliant Blue or blotted onto Hybond-C nitrocellulose membranes (GE Healthcare, Freiburg, Germany). The membranes were blocked with $5 \%(\mathrm{w} / \mathrm{v})$ skimmed milk in phosphate buffered saline (PBS) for $1 \mathrm{~h}$ and incubated with a polyclonal antibody against the $\mathrm{His}_{6}$ tag (Rockland Immunochemicals, Limerick, USA) for at least $2 \mathrm{~h}$ at room temperature (RT) with constant shaking. After washing, the membranes were incubated with a polyclonal alkaline phosphatase-conjugated goat antirabbit $\left(\mathrm{GAR}^{\mathrm{AP}}\right)$ secondary antibody (Dianova, Hamburg, Germany) and the signal was visualized with nitroblue tetrazolium chloride/5-bromo-4-chloro-3-indolyl phosphate (NBT/BCIP) $p$-toluidine salt (Carl Roth, Karlsruhe, Germany). The protein bands were compared with P7712S molecular weight markers (New England Biolabs, Ipswich, USA). All fractions containing the target protein were pooled and dialyzed against $100 \mathrm{mM}$ HEPES ( $\mathrm{pH}$ 7.5) overnight at $4{ }^{\circ} \mathrm{C}$ with one buffer change. The purified and quantified proteins were stored at $4{ }^{\circ} \mathrm{C}$.

Following dialysis, $0.5 \mathrm{mM} \mathrm{CuSO}_{4}$ was added to the laccase solution (Pozdnyakova and Wittung-Stafshede 2001) 
and the sample was mixed slowly on ice for $2 \mathrm{~h}$ before centrifugation $\left(30,000 \times g, 30 \mathrm{~min}, 4{ }^{\circ} \mathrm{C}\right)$ to remove any aggregates that may have formed during the incubation with $\mathrm{CuSO}_{4}$. The protein concentration was determined again by measuring the absorbance at $280 \mathrm{~nm}$ and using the molar extinction coefficient of the $S$. cyaneus laccase coding sequence including the $\mathrm{C}$-terminal $\mathrm{His}_{6}$ tag. The purified and quantified protein was stored briefly at $4{ }^{\circ} \mathrm{C}$ or was frozen in liquid nitrogen for long-term storage at $-80^{\circ} \mathrm{C}$

SDS-PAGE was used to analyze $13 \mu \mathrm{g}$ of the purified $S c$ Lac preparation. The enzyme solution was separated on 5-12\% Tris-glycine gels before staining with Coomassie Brilliant Blue, and the single protein band was compared to the P7712S molecular weight marker.

\section{Activity assays}

Zymography assays were used for the initial verification of enzyme activity. Otherwise, the activity assays for $S c$ Lac were based on spectrophotometry, using an Infinite ${ }^{\circledR} 200$ microplate reader (Tecan, Maennedorf Switzerland) at $30{ }^{\circ} \mathrm{C}$ in $100 \mathrm{mM}$ MES buffer (pH 5.5). Activity was tested by measuring the oxidation of the following substrates: 2,6-dimethoxyphenol (DMP; Sigma-Aldrich, Darmstadt, Germany) at $468 \mathrm{~nm}\left(\varepsilon=49,600 \mathrm{M}^{-1} \mathrm{~cm}^{-1}\right)$, ABTS at $420 \mathrm{~nm}\left(\varepsilon=36,000 \mathrm{M}^{-1} \mathrm{~cm}^{-1}\right)$ and guaiacol (Sigma-Aldrich, Darmstadt, Germany) at $465 \mathrm{~nm}\left(\varepsilon=26,600 \mathrm{M}^{-1} \mathrm{~cm}^{-1}\right)$. Control reactions were prepared under the same conditions with combinations of purified laccase and buffer, substrate and buffer, or buffer only. All activity assays were performed either in duplicates or in triplicates.

\section{Characterization of the purified enzyme}

The ultraviolet/visible (UV-Vis) spectra $(230-700 \mathrm{~nm}$ ) of $1 \mu \mathrm{M}$ purified ScLac was recorded before and after incubation with $\mathrm{CuSO}_{4}$ using an Infinite 200 plate reader. The activity assay before and after the incubation with $\mathrm{CuSO}_{4}$ was carried out using DMP as the substrate with $0.4 \mu \mathrm{M}$ ScLac.

The $\mathrm{pH}$ optimum of the laccase was determined by measuring the activity of the purified recombinant enzyme against DMP as described above, in a set of buffers with $\mathrm{pH}$ values ranging from 3.5 to 10.0. The buffers were $100 \mathrm{mM}$ sodium acetate $(\mathrm{pH} 3.5-5.0)$, $100 \mathrm{mM} 3$-( $N$-morpholino)propanesulfonic acid (MOPS) $(\mathrm{pH} \quad 5.5-7.5), \quad 100 \mathrm{mM}$ 2-amino-2-hydroxymethylpropane-1,3-diol hydrochloric acid (Tris-HCl) $(\mathrm{pH}$ 8.0-8.5) and $100 \mathrm{mM}$ glycine sodium hydroxide $(\mathrm{pH}$ 9.0-10.0). Each reaction was prepared with $0.4 \mu \mathrm{M}$ $S c$ Lac and the reactions were followed at $468 \mathrm{~nm}$ for $15 \mathrm{~min}$. Enzyme stability in the optimal buffer system was determined by incubating $0.4 \mu \mathrm{M} \mathrm{ScLac}$ for 1,6 and $24 \mathrm{~h}$ at $30^{\circ} \mathrm{C}$ before measuring residual activities against DMP as described above. Control reactions were set up with $0.4 \mu \mathrm{M}$ laccase without incubation at $30^{\circ} \mathrm{C}$.

The temperature optimum of $\mathrm{ScLac}$ was determined by incubating $0.4 \mu \mathrm{M}$ of the enzyme with $20 \mu \mathrm{M}$ DMP in $100 \mathrm{mM}$ MES buffer ( $\mathrm{pH}$ 5.5) at various temperatures ranging from 25 to $90{ }^{\circ} \mathrm{C}$ for $5 \mathrm{~min}$, and then measuring the absorbance values as described for DMP above. The influence of temperature on laccase stability was determined by incubating $0.4 \mu \mathrm{M} S c \mathrm{Lac}$ in $100 \mathrm{mM}$ MES buffer (pH 5.5) at 25, 30, 60 and $90{ }^{\circ} \mathrm{C}$ for $1 \mathrm{~h}$, then chilling the protein samples on ice for $5 \mathrm{~min}$ and measuring the residual enzyme activity using DMP as described above. The diagrams for the characterization of ScLac were based on relative activities calculated by assigning the highest value in the dataset representing each enzyme as $100 \%$.

Kinetic parameters were analyzed by measuring enzyme activities against guaiacol, DMP and ABTS (as described above) over the concentration range 5-95 $\mu \mathrm{M}$ under the optimal assay conditions. Kinetic constants were analyzed and calculated using GraphPad Prism v6 software (Statcon, Germany).

\section{Immobilization of ScLac}

A sample of purified ScLac was immobilized using two different methods: cross linked enzyme aggregates (CLEAs) and AminoLink ${ }^{\mathrm{TM}}$ Plus Coupling Resin (Thermo Fisher Scientific, Darmstadt, Germany). The latter was used as a carrier material benefiting from the Schiff base reaction between the primary amines of the protein and the aldehyde groups of the resin.

CLEAs were prepared as follows: $2.5 \mathrm{~mL}$ of $1 \mathrm{~g} \mathrm{~mL}^{-1}$ polyethylene glycol (PEG) 4000 was added dropwise to $5 \mathrm{mg}$ of a purified ScLac sample on ice and incubated at $20^{\circ} \mathrm{C}$ for $2 \mathrm{~h}$, shaking at $200 \mathrm{rpm}$. The sample was mixed with $5 \mathrm{mM}$ glutaraldehyde and incubated overnight under the same conditions. The CLEAs were then collected by centrifugation $\left(5000 \times g, 10 \mathrm{~min}, 4{ }^{\circ} \mathrm{C}\right)$. The supernatant was removed and an activity assay with DMP was carried out as described above to check for free laccase in the washing fraction. The washing steps were repeated until no activity was detected in the washing buffer and the CLEAs were then resuspended in $1 \mathrm{~mL}$ $0.1 \mathrm{M}$ MES buffer ( $\mathrm{pH}$ 5.5). The activity recovery after the CLEA protocol was calculated by dividing the CLEA activity $(\mathrm{U})$ by the activity of the free enzyme $\left(\mathrm{U} \mathrm{L}^{-1}\right)$ multiplied by the volume of the free enzyme used for immobilization, and then multiplying the resulting value by 100 (Eq. 1) (Lopez-Gallego et al. 2005).

Calculation of the activity recovery (\%) of prepared CLEAs. A $\mathrm{A}_{\text {CLEA }}$ :

$$
\text { Activity recovery }(\%)=\frac{A_{\text {CLEA }}}{A_{\text {free }} \times V_{\text {free }}} \times 100
$$


where activity $(\mathrm{U})$ of prepared CLEA; $\mathrm{A}_{\text {Free }}$ : activity $\left(\mathrm{U} \mathrm{mL} \mathrm{mL}^{-1}\right)$ of free enzyme; $\mathrm{V}_{\text {Free: }}$ volume $(\mathrm{mL})$ of free enzyme used to prepare CLEAs.

Immobilization on AminoLink ${ }^{\mathrm{TM}}$ Plus Coupling Resin was achieved by mixing approximately $5 \mathrm{mg}$ of purified ScLac with 10-50 $\mu \mathrm{m}$ aldehyde-functionalized agarose beads provided as a $50 \%$ slurry in $0.02 \%$ sodium azide buffer. The immobilization protocol was performed in $10 \mathrm{~mL}$ gravity-flow columns (Bio-Rad, Munich, Germany) that were never allowed to run dry. The columns were loaded with $500 \mu \mathrm{L}$ of the bead slurry before equilibration with $6 \mathrm{~mL}$ coupling buffer $(0.1 \mathrm{M}$ sodium phosphate, $0.15 \mathrm{M} \mathrm{NaCl}, \mathrm{pH}$ 7.2). The columns were then loaded with $4.5 \mathrm{~mL}$ of the protein sample $\left(1.11 \mathrm{mg} \mathrm{mL}^{-1}\right)$ and the slurry was mixed for $3-4 \mathrm{~h}$ at $4{ }^{\circ} \mathrm{C}$. The samples were then drained and the beads were equilibrated in $3 \mathrm{~mL}$ coupling buffer before adding $1 \mathrm{~mL}$ $0.1 \mathrm{M}$ sodium cyanoborohydride in coupling buffer and mixing overnight at $4{ }^{\circ} \mathrm{C}$. The reaction buffer was drained and the beads were equilibrated with $2 \mathrm{~mL}$ quenching buffer (1 M Tris-HCl, $\mathrm{pH}$ 7.4). Following the equilibration, $1 \mathrm{~mL} 0.1 \mathrm{M}$ sodium cyanoborohydride in quenching buffer was added to the beads and the slurry was mixed for a further $90 \mathrm{~min}$. To complete the immobilization, the beads were washed with $6 \mathrm{~mL}$ washing buffer and stored in $500 \mu \mathrm{L}$ immobilization storage buffer.

The protein concentration on the beads was calculated by subtracting the mass of protein after the first reaction step and the mass of the protein lost during the washing steps from the initial mass of protein, and dividing this by the volume of the bead slurry after immobilization. Protein concentrations for immobilization experiments were determined using the bicinchoninic acid assay (Pierce ${ }^{\mathrm{TM}}$ BCA Protein Assay Kit, Thermo Fisher Scientific, Darmstadt, Germany) according to the manufacturer's protocol. All samples and standards were measured either in duplicates or triplicates.

The reusability of the immobilized laccase preparations was assessed in five sequential activity assays against DMP. Immediately prior to the reusability assay, the enzyme samples were mixed vigorously. After each activity assay, beads and CLEAs were collected by either gravity or centrifugation $\left(15,000 \times g, 5 \mathrm{~min}, 4{ }^{\circ} \mathrm{C}\right)$ and washed three times. Temperature stability and $\mathrm{pH}$ optima were determined as described above. The diagrams for the characterization of immobilized ScLac preparations were based on relative activities calculated by assigning the highest value in each dataset as $100 \%$ (except for the reusability assay). For the reusability assay, the first measurement in each dataset was set to $100 \%$.

\section{Results}

Heterologous expression of S. cyaneus CECT 3335 laccase in $E$. coli and purification by IMAC

Streptomyces cyaneus CECT 3335 laccase with a C-ter-

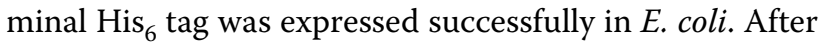
purification by single-step IMAC, SDS-PAGE analysis revealed a strong band for the enzyme preparation near the $70 \mathrm{kDa}$ marker agreeing with the predicted molecular mass of $69.5 \mathrm{kDa}$ (Fig. 1). High yields (up to $104 \mathrm{mg} \mathrm{L}^{-1}$ ) of purified recombinant $S c$ Lac were achieved using $E$. coli, suggesting that despite its simplicity, it remains a promising host organism for the production of substantial amounts of this enzyme for further biotechnological applications.

\section{Analysis of the enzymatic activity and functional properties of recombinant ScLac}

The visible spectra of the purified ScLac correlated with the typical spectra of blue laccases. A peak at $\sim 600 \mathrm{~nm}$, which was detected only after incubation with $\mathrm{CuSO}_{4}$, indicated that the T1 copper atom was incorporated into the protein structure (Thurston 1994) (Fig. 2). Activity assays using DMP before and after incubation with $\mathrm{CuSO}_{4}$ confirmed that the laccase was expressed as an apoprotein in E. coli and the addition of copper was necessary for the maturation and activation of the enzyme (Additional file 1: Fig. S1). Zymography assays using ABTS, L-DOPA and caffeic acid as substrates (Additional

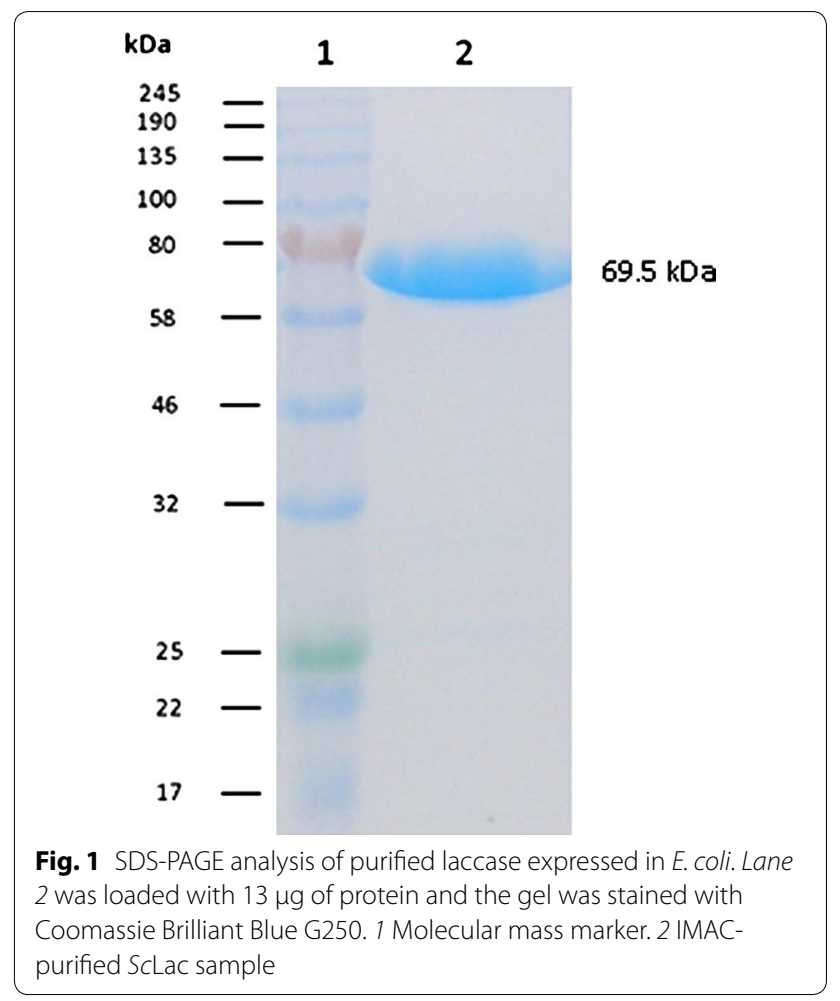




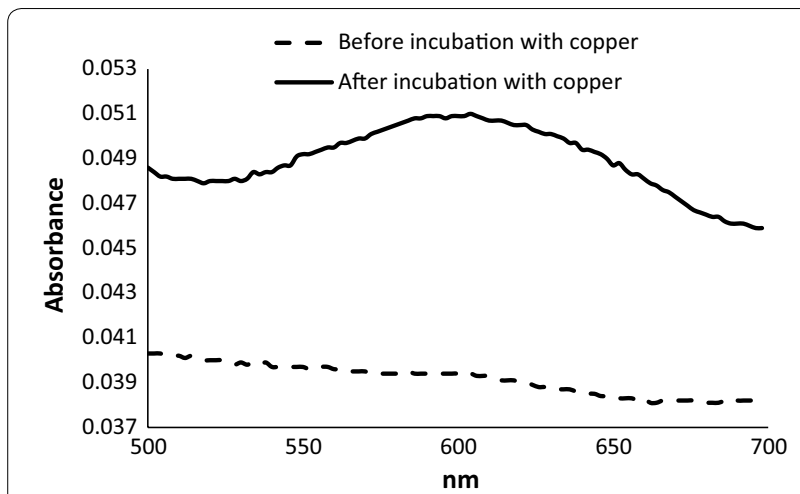

Fig. 2 Visible spectra of ScLac before (dashed line) and after (solid line) incubation with $0.5 \mathrm{mM} \mathrm{CuSO}_{4}$. We used $1 \mu \mathrm{M}$ of recombinant enzyme to record the visible spectra between 500 and $700 \mathrm{~nm}$

file 1: Fig. S2) also confirmed laccase activity following incubation with $\mathrm{CuSO}_{4}$.

The $\mathrm{pH}$ activity profile of the purified laccase was determined using DMP as the substrate with a set of buffers covering a broad $\mathrm{pH}$ range $(\mathrm{pH} 3.5-10.0)$. The recombinant $S c$ Lac reached its maximum activity at $\mathrm{pH}$ 5.5 (Fig. 3a), and was active across a broad range of $\mathrm{pH}$ values ( $\mathrm{pH} 3.5-8.5)$. The $\mathrm{pH}$ stability of $S c \mathrm{Lac}$ was investigated by incubating an aliquot of the purified enzyme preparation in the same buffer set used to determine the $\mathrm{pH}$ optima for 0, 1, 6 and $24 \mathrm{~h}$ (Fig. 4a). ScLac generally lost activity over time, but the decline was more rapid at $\mathrm{pH} 3.5-5.5$ than at $\mathrm{pH}$ values $>6$. Although $S c$ Lac had a $\mathrm{pH}$ optimum of 5.5 , the stability profile suggested that the enzyme is also active at neutral and basic $\mathrm{pH}$ values.

ScLac showed high activity at elevated temperatures, as previously described for other bacterial laccases and laccase-like multi-copper oxidases (LMCOs) (Ihssen et al. 2015; Koschorreck et al. 2008; Martins et al. 2002; Reiss et al. 2011; Sherif et al. 2013). It also showed a broad optimum temperature range of $30-90{ }^{\circ} \mathrm{C}$ (Fig. 3b). The heat stability of the recombinant enzyme was also determined during longer incubation periods. ScLac was incubated at 30,60 and $90{ }^{\circ} \mathrm{C}$ for $1 \mathrm{~h}$ and subsequently tested for the remaining activity against DMP (Fig. 4b). The activity of the recombinant laccase increased during the incubation at $30{ }^{\circ} \mathrm{C}$ and it retained $50 \%$ of its initial
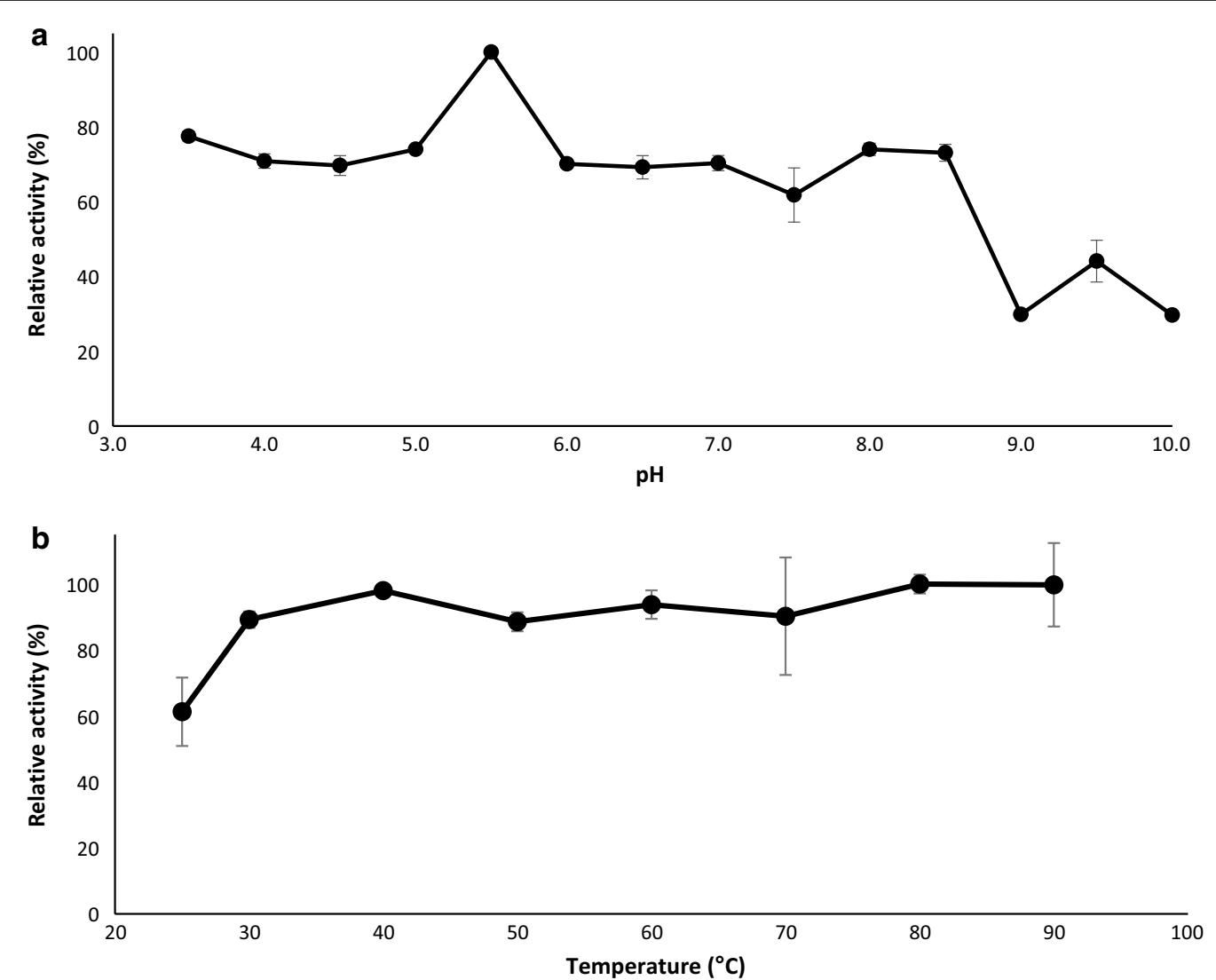

Fig. 3 Optimum pH (a) and temperature (b) profiles of SCLac. a The activity of the laccase was measured against $20 \mu M$ DMP at $30^{\circ} \mathrm{C}$ in buffers with various $\mathrm{pH}$ values ranging from $\mathrm{pH}$ 3.5-10.0. b The activity of the laccase was measured against $20 \mu \mathrm{M}$ DMP after incubation for 5 min in the optimal buffer system in a temperature range from 25 to $90^{\circ} \mathrm{C}$ 

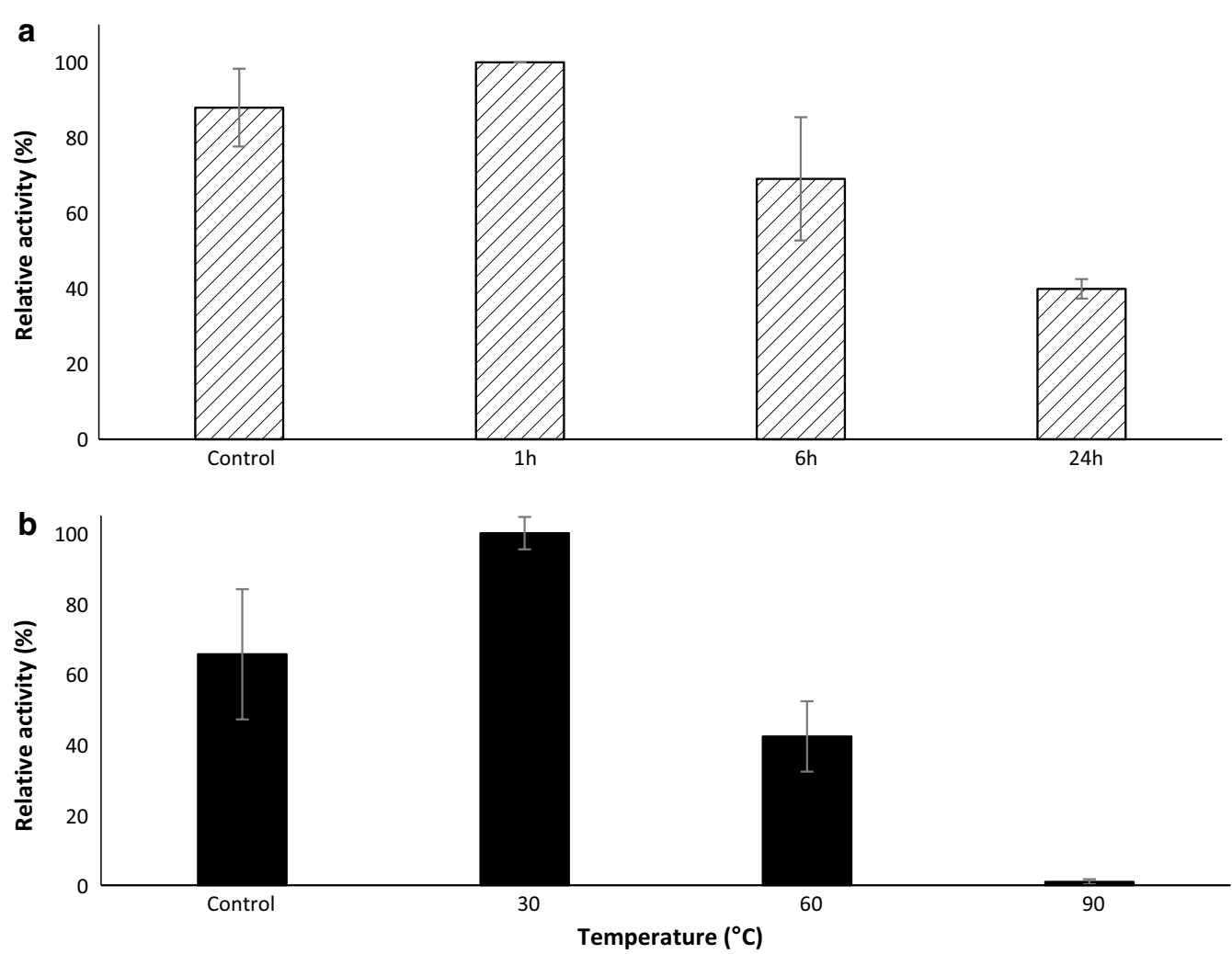

Fig. 4 The $\mathrm{pH}(\mathbf{a})$ and thermal (b) stability profiles of ScLac. a We incubated $0.4 \mu \mathrm{M} \mathrm{SCLac}$ in the optimal pH buffer for 1,6 and $24 \mathrm{~h}$ at $30^{\circ} \mathrm{C}$ and the residual activity was measured using $20 \mu \mathrm{M}$ DMP. b We incubated $0.4 \mu \mathrm{M} \mathrm{ScLac}$ at 30,60 and $90^{\circ} \mathrm{C}$ for $1 \mathrm{~h}$ in the optimal pH buffer and the residual activities were tested against $20 \mu \mathrm{M}$ DMP. Control assays were set up without $\mathrm{pH}$ or heat treatment

activity following incubation at $60^{\circ} \mathrm{C}$ but lost most of its activity at $90^{\circ} \mathrm{C}$.

\section{Determination of substrate specificity and steady-state kinetics}

The specific activities and kinetic constants were determined using three common laccase substrates (DMP, ABTS and guaiacol) that are also used to test other lignin-degrading enzymes such as peroxidases (Table 1). The kinetic parameters for this particular laccase are presented here for the first time and fit within the range of

Table 1 Specific activities and kinetic constants of ScLac against DMP, ABTS and guaiacol

\begin{tabular}{lcll}
\hline & DMP & ABTS & Guaiacol \\
\hline $\begin{array}{c}\text { Specific activity } \\
\left(\cup \mathrm{mg}^{-1}\right)\end{array}$ & $0.540 \pm 0.020$ & $2.9400 \pm 0.1700$ & $0.0190 \pm 0.0010$ \\
$\mathrm{Km}(\mathrm{mM})$ & $0.2016 \pm 0.0348$ & $0.0335 \pm 0.0279$ & $0.0054 \pm 0.0019$ \\
$\operatorname{Vmax}(\mathrm{U})$ & $0.0053 \pm 0.0007$ & $0.0003 \pm 0.0002$ & $0.0002 \pm 0.0000$ \\
$\mathrm{kcat}\left(\mathrm{min}^{-1}\right)$ & $57.30 \pm 8.10$ & $3.4640 \pm 1.8640$ & $1.6740 \pm 0.0876$ \\
\hline
\end{tabular}

values reported for other recombinant bacterial laccases (Dwivedi et al. 2011; Ihssen et al. 2015).

\section{Immobilization of ScLac}

ScLac was immobilized on agarose beads and by the preparation of CLEAs, the latter mediated by PEG precipitation and glutaraldehyde cross-linking. At the end of the CLEA procedure, $71.5 \%$ of the initial activity was recovered. The immobilization of $S c \mathrm{Lac}$ on agarose beads using a Schiff base reaction achieved 33\% immobilization efficiency (the proportion of bound protein). The reusability of the immobilized enzyme preparations was tested by performing five sequential activity assays using DMP as the substrate. The laccase immobilized on agarose beads maintained its activity in all five steps. The activity of the CLEAs declined to $~ 60 \%$ of the initial activity over the five steps, but the heat activation detected in the free enzyme sample was also observed in the CLEA preparation (Fig. 5).

The stability of the immobilized ScLac was tested after $1 \mathrm{~h}$ incubation at $30^{\circ} \mathrm{C}$ and compared to the free laccase. The laccase immobilized on agarose beads retained $70 \%$ of its initial activity whereas the CLEAs retained $88 \%$ of 

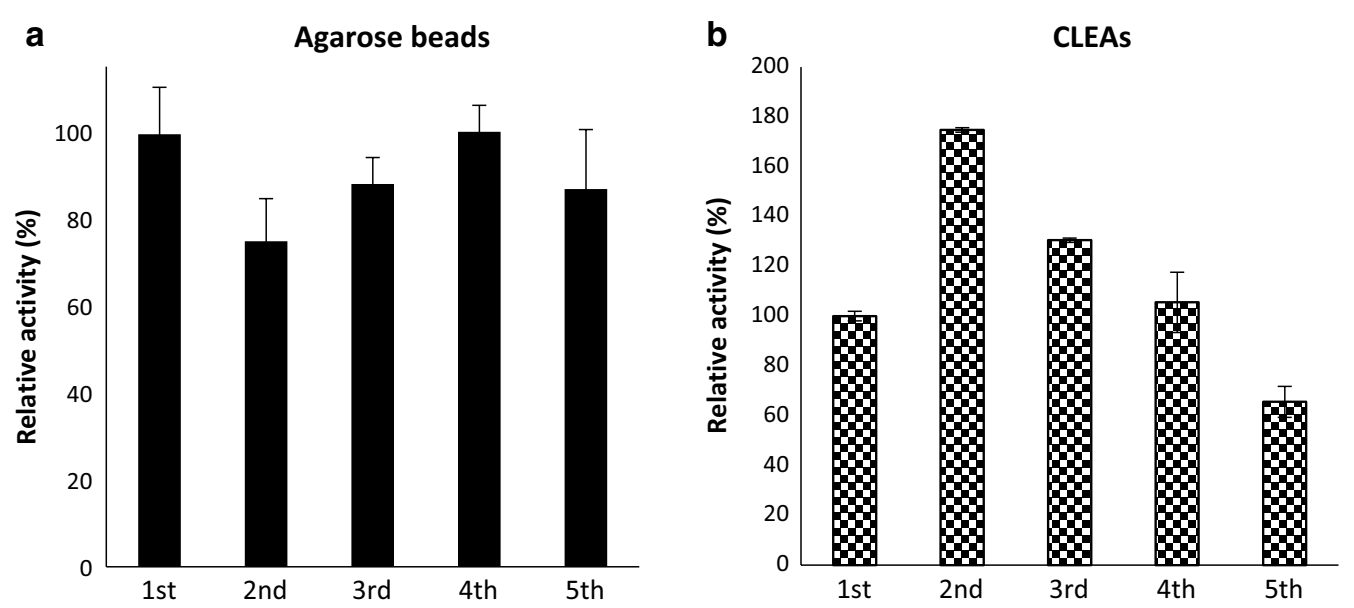

Fig. 5 The reusability of immobilized SCLac. The remaining activity of immobilized SCLac on agarose beads (a) or as CLEAs (b) was analyzed in sequential activity assays for five cycles using DMP as the substrate

their initial activity (Fig. 6a). The pH optima of the immobilized enzymes were also determined and were found to differ from the free enzyme preparation most likely due to changes in the structural conformation of the enzyme or the microenvironment induced by the immobilization method or the matrix (Bussamara et al. 2012; Guzik et al. 2014; Kumar et al. 2014). The laccase immobilized on agarose beads reached maximum activity at $\mathrm{pH} 6.5$ and the CLEAs reached maximum activity at $\mathrm{pH} 4.5$ (Fig. 6b). Although the immobilized ScLac can be reused at least five times, neither the stability nor the activity of the immobilized enzyme improved compared to the free enzyme.

\section{Discussion}

Laccases are found in all three domains of life and catalyze biotechnologically significant reactions. The characterization of bacterial laccases has shown that they have unique properties and are more advantageous than laccases from fungi and plants. However, the yield of purified bacterial laccases is a limiting factor for biotechnological applications. Here we expressed a laccase from the lignocellulose-mineralizing bacterium $S$. cyaneus in $E$. coli for the first time, achieving high yields of the soluble recombinant enzyme $\left(104 \mathrm{mg} \mathrm{L}^{-1}\right)$. The extracellular expression of ScLac in its native host was previously carried out for 10 days in a submerged culture, yielding $8.19 \mathrm{mg}$ protein from $100 \mathrm{~mL}$ of culture supernatant following five purification steps (Arias et al. 2003; Margot et al. 2013). In contrast, the heterologous expression of $S c$ Lac in $E$. coli achieved higher yields in a shorter cultivation time and required only a single affinity chromatography purification step.
Several recombinant bacterial laccases have been expressed in E. coli, but in most cases the yields were poor (Table 2). Whereas low yields in homologous systems may be caused by the need for submerged cultures, heterologous systems face challenges such as codon usage bias, the need for signal peptides, protein accumulation as inclusion bodies, the absence of necessary posttranslational modifications, and enzyme inactivation during purification (Brijwani et al. 2010; Piscitelli et al. 2010). The heterologous expression of CotA laccase from Bacillus subtilis in E. coli has been achieved by several groups and has led to detailed characterization studies, structural and functional analysis, and the use of protein evolution to improve the yields of recombinant enzyme (Bento et al. 2005; Brissos et al. 2009; Martins et al. 2002; Osipov et al. 2015). A blue multi-copper oxidase from Marinomonas mediterranea (PpoA) was expressed in $E$. coli BL21 (DE3) and laccase activity was observed against the substrates L-3,4-dihydroxyphenylalanine (L-DOPA), DMP and syringaldazine (SGZ) in the soluble fractions of the cell extracts (Sanchez-Amat et al. 2001). However, the yield of the recombinant enzyme was not reported and the purification strategy was not described. A laccase-like phenol oxidase from Streptomyces griseus (EpoA) was expressed in $E$. coli with a C-terminal $\mathrm{His}_{6}$ tag for purification by affinity chromatography and ion exchange chromatography (Endo et al. 2003). A thermostable laccase from Streptomyces lavenduale was expressed in E. coli with a yield of up to $30 \mathrm{mg} \mathrm{L}^{-1}$ and $10 \mathrm{mg}$ of pure protein was isolated after five purification steps (Suzuki et al. 2003).

Other laccases and LMCOs have been expressed in $E$. coli (Table 2) including the Lbh1 multi-copper oxidase from Bacillus halodurans, which has alkaline laccase 

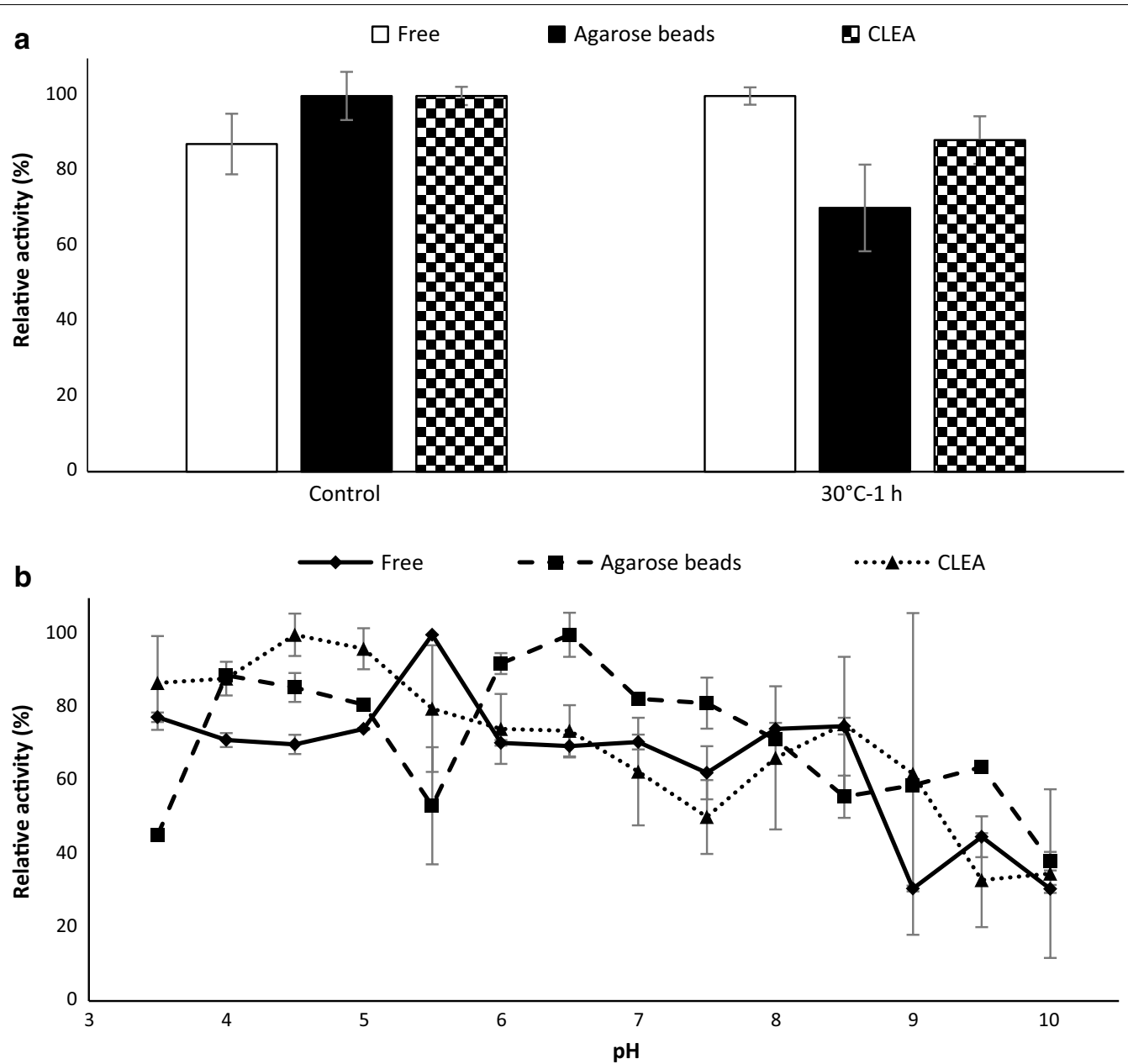

Fig. 6 Characterization of immobilized and free SCLac. a Thermal stability was determined by incubating the free and immobilized enzymes at $30^{\circ} \mathrm{C}$ for $1 \mathrm{~h}$ and measuring the residual activities. Control assays were set up without heat treatment. $\mathbf{b}$ Optimum pH profiles of free ScLac, ScLac immobilized on agarose beads and ScLac CLEAs

activity (Ruijssenaars and Hartmans 2004), a small laccase from Streptomyces coelicolor (SLAC) (Machczynski et al. 2004), the hyperthermophilic Tth laccase from Thermus thermophilus (Miyazaki 2005), a robust metallooxidase (McoA) from the hyperthermophilic bacterium Aquifex aeolicus (Fernandes et al. 2007), CotA laccases from Bacillus spp. (Brander et al. 2014; Guan et al. 2014; Koschorreck et al. 2008), and a pH-versatile, saltresistant laccase from Streptomyces ipomoea (SilA) (Molina-Guijarro et al. 2009). Although the heterologous expression of these bacterial laccases in E. coli made it possible to characterize the recombinant laccases and perform detailed structural analysis, the yields were often low or the proteins formed inclusion bodies, which made purification more laborious. In contrast, we achieved the production of substantial amounts of a recombinant laccase for further applications.
UV/Vis spectra of the recombinant $S c$ Lac preparation and subsequent activity assays showed that the T1 copper was not incorporated into the recombinant protein structure during its expression in E. coli. A similar phenomenon was reported for recombinant EpoA, which was only active when expressed in the presence of $10 \mu \mathrm{M} \mathrm{CuSO}_{4}$. Otherwise, the enzyme accumulated in an inactive monomeric form (Endo et al. 2003). However, the addition of copper to the expression medium might not be advisable because excess copper is toxic and may inhibit cell growth (Bird et al. 2013; Grey and Steck 2001). The incorporation of the T1 copper into $S c$ Lac was achieved by incubating the purified enzyme preparation in a buffer system containing $0.5 \mathrm{mM}$ copper, and confirmed by UV-Vis spectra and subsequent activity assays. Unlike T1 copper, the verification of T2 and T3 copper incorporation requires other techniques such as 
Table 2 Bacterial laccases, laccase-like phenol oxidases and multi-copper oxidases produced by heterologous expression in E. coli

\begin{tabular}{|c|c|c|c|c|}
\hline Enzyme & Origin & Yield & Comments & Reference \\
\hline PpoA & Marinomonas mediterranea & NR & & Sanchez-Amat et al. (2001) \\
\hline $\operatorname{Cot} A$ & Bacillus subtilis & NR & $\begin{array}{l}10 \% \text { of total recombinant CotA } \\
\text { expressed by E. coli was purified } \\
\text { successfully }\end{array}$ & Martins et al. (2002) \\
\hline $\operatorname{Cot} \mathrm{A}$ & B. subtilis & $\begin{array}{l}20 \mathrm{mg} \mathrm{L}^{-1} \text { (aerobic) } \\
23 \mathrm{mg} \mathrm{L}^{-1} \text { (anaerobic) }\end{array}$ & & $\begin{array}{l}\text { Durao et al. }(2006,2008 a, b) \text {; Pereira et al. } \\
\text { (2009) }\end{array}$ \\
\hline EpoA & Streptomyces griseus & NR & & Endo et al. (2003) \\
\hline STSL & Streptomyces lavendulae & $10 \mathrm{mg} \mathrm{L}^{-1}$ & & Suzuki et al. (2003) \\
\hline Lbh1 & Bacillus halodurans & NR & & Ruijssenaars and Hartmans (2004) \\
\hline SLAC & Streptomyces coelicolor & NR & & Machczynski et al. (2004) \\
\hline Tth laccase & Thermus thermophilus & $10 \mathrm{mg} \mathrm{L}^{-1}$ & & Miyazaki (2005) \\
\hline McoA & Aquifex aeolicus & NR & $\begin{array}{l}\text { Expressed as insoluble protein and } \\
\text { recovered by unfolding and refolding }\end{array}$ & Fernandes et al. (2007) \\
\hline $\operatorname{Cot} \mathrm{A}$ & Bacillus licheniformis & $10 \mathrm{mg} \mathrm{L}^{-1}$ & & Koschorreck et al. (2008) \\
\hline SilA & Streptomyces ipomea & NR & $\begin{array}{l}\text { 4.8-fold purification of the protein } \\
\text { corresponding to a final yield of } \\
85.6 \%\end{array}$ & Molina-Guijarro et al. (2009) \\
\hline LCMOs & $\begin{array}{l}\text { Bacillus coagulans } \\
\text { Bacillus clausii } \\
\text { Bacillus pumilus } \\
\text { Streptomyces pristinaespiralis } \\
\text { Gramella forsetii } \\
\text { Marivirga tractuosa } \\
\text { Spirosoma linguale }\end{array}$ & NR & & Ihssen et al. (2015) \\
\hline $\begin{array}{l}\text { SCLAC } \\
\text { SLLAC } \\
\text { SVLAC } \\
\text { AMLAC }\end{array}$ & $\begin{array}{l}\text { S. coelicolor } \\
\text { Streptomyces lividans } \\
\text { Streptomyces viridosporus } \\
\text { Amycolatopsis sp. }\end{array}$ & $15-20 \mathrm{mg} \mathrm{L}^{-1}$ & & Majumdar et al. (2014) \\
\hline $\operatorname{Cot} A$ & B. clausii & NR & & Brander et al. (2014) \\
\hline Ssl1 & Streptomyces sviceus & $40-50 \mathrm{mg} \mathrm{L}^{-1}$ & & Gunne and Urlacher (2012) \\
\hline BALL & B. licheniformis & $20 \mathrm{mg} \mathrm{L}^{-1}$ & & Tonin et al. (2016) \\
\hline MmPPO & Marinomonas mediterranea & NR & $\begin{array}{l}\text { Recovered from membrane fraction } \\
\text { and partially purified to } 34 \cup \mathrm{L}^{-1}\end{array}$ & Tonin et al. (2016) \\
\hline
\end{tabular}

The enzyme yield is the amount of enzyme recovered after purification

NR not reported

EPR rather than UV-Vis spectra. After incubation with $\mathrm{CuSO}_{4}$, enzymatic activity tests by zymography revealed laccase activity against ABTS, L-DOPA and caffeic acid. Further analysis of specific activities and kinetics showed that the recombinant $S c$ Lac was most active against ABTS followed by DMP and guaiacol, similar to other bacterial laccases.

The recombinant $S c$ Lac showed broad optimum $\mathrm{pH}$ and temperature ranges. $S c$ Lac showed its maximum activity at $\mathrm{pH} 5.5$ and it retained its stability at neutral and basic $\mathrm{pH}$ values, in agreement with reports describing other bacterial laccases. This leads to the suggestion that $S c$ Lac also might be ideal for biotechnological applications where neutral or basic $\mathrm{pH}$ values are required over a longer period (Brander et al. 2014; Gunne and Urlacher 2012; Ruijssenaars and Hartmans 2004). An activity at neutral or basic $\mathrm{pH}$ values is often observed for bacterial laccases and laccase-like enzymes but less frequently for the fungal laccases (Christopher et al. 2014). For example, B. halodurans Lbh1 showed maximum activity against SGZ at pH 7.5-8.0, Streptomyces sviceus Ssl1 showed maximum activity against phenolic substrates such as DMP and guaiacol at pH 9.0 and against SGZ at $\mathrm{pH}$ 8.0, and a halotolerant alkaline laccase from Streptomyces psammoticus showed maximum activity at $\mathrm{pH} 8.5$ and retained $97 \%$ of its initial activity after $90 \mathrm{~min}$ at pH 9.0 (Gunne and Urlacher 2012; Niladevi et al. 2008; Ruijssenaars and Hartmans 2004). High activities in alkaline solutions are ideal for industrial applications such as the bio-bleaching of Kraft pulp during paper production, lignin modification and total biomass degradation (Pometto and Crawford 1986; Ruijssenaars 
and Hartmans 2004; Si et al. 2015). Laccases often remain active for a short time at high temperatures (Reiss et al. 2011; Zhang et al. 2013) but industrial applications usually require prolonged reactions. Although ScLac lost most of its activity following the incubation at $90{ }^{\circ} \mathrm{C}$, the stability profiles at 30 and $60{ }^{\circ} \mathrm{C}$ were promising. A phenomenon known as heat activation, which has already been reported for a Bacillus clausii LMCO expressed in E. coli (Brander et al. 2014), was observed for ScLac after incubation at $30^{\circ} \mathrm{C}$.

The cost of enzyme production is a major factor in the economics of enzyme-based biomass degradation processes and is dependent on the host cells and purification strategy (Klein-Marcuschamer et al. 2012). Such costs can be minimized if the enzyme is reused in multiple process cycles by means of immobilization. In this study, ScLac was immobilized using two distinct methods: agarose beads and cross-linked enzyme aggregates (CLEA). Unlike reported for several laccases (Cabana et al. 2007; Sinirlioğlu et al. 2013), the stability of immobilized ScLac was not improved in comparison to the free enzyme. However, the recovery and reusability of the enzyme was demonstrated successfully, suggesting that ScLac could be used for the development of costefficient biotechnological processes (Robinson 2015).

\section{Additional file}

Additional file 1. Additional figures.

\begin{abstract}
Abbreviations
ABTS: 2,2'-azinobis(3-ethylbenzothiazoline-6-sulfonate); CLEA: cross-linked enzyme aggregate; DMP: 2,6-dimethoxyphenol; IMAC: immobilized metal affinity chromatography; L-DOPA: L-3,4-dihydroxyphenylalanine; LMCO: laccase-like multi-copper oxidase; LMS: laccase mediator system; MOPS: 3-(N-morpholino) propanesulfonic acid; PBS: phosphate-buffered saline; PEG: polyethylene glycol; PMSF: phenylmethylsulfonyl fluoride; RT: room temperature; SCLac: laccase from Streptomyces cyaneus expressed in E. coli; SDS-PAGE: sodium dodecylsulfate polyacrylamide gel electrophoresis; SGZ: syringaldezine(4-hydroxy-3,5-dimethoxybenzaldehyde azine); VA: veratryl alcohol.
\end{abstract}

\section{Authors' contributions}

SE designed and carried out the experiments, analyzed the results and wrote the manuscript. CL assisted in the experimental design and the interpretation of data, and reviewed the manuscript. RF and UC coordinated the study and reviewed the manuscript. All authors read and approved the final manuscript.

\section{Author details}

1 Institute for Molecular Biotechnology (Biology VII), RWTH Aachen University, Worringerweg 1, 52074 Aachen, Germany. ${ }^{2}$ Fraunhofer Institute for Molecular Biology and Applied Ecology (IME), Forckenbeckstrasse 6, 52074 Aachen, Germany.

\section{Acknowledgements}

The authors are grateful to Dr. Richard Twyman for his assistance with editing the manuscript.

\section{Competing interests}

The authors declare that they have no competing interests.

\section{Availability of data and materials}

The data supporting the findings of this study are included in the main manuscript file and in the additional files.

\section{Funding}

We acknowledge financial support from the European Commission via the SuBiCat Initial Training Network, Call FP7-PEOPLE-2013-ITN (PITN-GA-2013-607044), and the Cluster of Excellence'Tailor-made Fuels from Biomass' (EXC 236), which is funded through the Excellence Initiative by the German federal and state governments to promote science and research at German universities.

\section{Publisher's Note}

Springer Nature remains neutral with regard to jurisdictional claims in published maps and institutional affiliations.

Received: 7 April 2017 Accepted: 11 April 2017

Published online: 24 April 2017

\section{References}

Arias ME, Arenas M, Rodriguez J, Soliveri J, Ball AS, Hernandez M (2003) Kraft pulp biobleaching and mediated oxidation of a nonphenolic substrate by laccase from Streptomyces cyaneus CECT 3335. Appl Environ Microbiol 69(4):1953-1958

Ausec L, van Elsas JD, Mandic-Mulec I (2011) Two- and three-domain bacterial laccase-like genes are present in drained peat soils. Soil Biol Biochem 43(5):975-983

Bento I, Martins LO, Gato Lopes G, Armenia Carrondo M, Lindley PF (2005) Dioxygen reduction by multi-copper oxidases: a structural perspective. Dalton Trans (21):3507-3513. doi:10.1039/b504806k

Bird LJ, Coleman ML, Newman DK (2013) Iron and copper act synergistically to delay anaerobic growth of bacteria. Appl Environ Microbiol 79(12):36193627. doi:10.1128/Aem.03944-12

Brander S, Mikkelsen JD, Kepp KP (2014) Characterization of an alkali- and halide-resistant laccase expressed in E. coli: cotA from Bacillus clausii. PLoS ONE 9(6):e99402. doi:10.1371/journal.pone.0099402

Brijwani K, Rigdon A, Vadlani PV (2010) Fungal laccases: production, function, and applications in food processing. Enzyme Res 2010:149748. doi:10.4061/2010/149748

Brissos V, Pereira L, Munteanu FD, Cavaco-Paulo A, Martins LO (2009) Expression system of CotA-laccase for directed evolution and high-throughput screenings for the oxidation of high-redox potential dyes. Biotechnol J 4(4):558-563. doi:10.1002/biot.200800248

Bugg TD, Ahmad M, Hardiman EM, Singh R (2011) The emerging role for bacteria in lignin degradation and bio-product formation. Curr Opin Biotechnol 22(3):394-400. doi:10.1016/j.copbio.2010.10.009

Bussamara R, Dall'agnol L, Schrank A, Fernandes KF, Vainstein MH (2012) Optimal conditions for continuous immobilization of Pseudozyma hubeiensis (strain HB85A) lipase by adsorption in a packed-bed reactor by response surface methodology. Enzyme Res 2012:329178. doi:10.1155/2012/329178

Cabana H, Jones JP, Agathos SN (2007) Preparation and characterization of cross-linked laccase aggregates and their application to the elimination of endocrine disrupting chemicals. J Biotechnol 132(1):23-31. doi:10.1016/j.jbiotec.2007.07.948

Call HP, Mücke I (1997) History, overview and applications of mediated lignolytic systems, especially laccase-mediator-systems (Lignozym(R)-process). J Biotechnol 53(2-3):163-202. doi:10.1016/S0168-1656(97)01683-0

Canas Al, Camarero S (2010) Laccases and their natural mediators: biotechnological tools for sustainable eco-friendly processes. Biotechnol Adv 28(6):694-705. doi:10.1016/j.biotechadv.2010.05.002

Chandra R, Chowdhary P (2015) Properties of bacterial laccases and their application in bioremediation of industrial wastes. Environ Sci Process Impacts 17(2):326-342. doi:10.1039/c4em00627e

Chen Q, Marshall MN, Geib SM, Tien M, Richard TL (2012) Effects of laccase on lignin depolymerization and enzymatic hydrolysis of ensiled corn stover. Bioresour Technol 117:186-192. doi:10.1016/j.biortech.2012.04.085 
Christopher LP, Yao B, Ji Y (2014) Lignin biodegradation with laccase-mediator systems. Front Energy Res 2:12

Claus H (2003) Laccases and their occurrence in prokaryotes. Arch Microbiol 179(3):145-150. doi:10.1007/s00203-002-0510-7

de Marco A, Vigh L, Diamant S, Goloubinoff P (2005) Native folding of aggregation-prone recombinant proteins in Escherichia coli by osmolytes, plasmid- or benzyl alcohol-overexpressed molecular chaperones. Cell Stress Chaperon 10(4):329-339. doi:10.1379/Csc-139r.1

Durao P, Bento I, Fernandes AT, Melo EP, Lindley PF, Martins LO (2006) Perturbations of the T1 copper site in the CotA laccase from Bacillus subtilis: structural, biochemical, enzymatic and stability studies. J Biol Inorg Chem 11(4):514-526. doi:10.1007/s00775-006-0102-0

Durao P, Chen Z, Fernandes AT, Hildebrandt P, Murgida DH, Todorovic S, Pereira MM, Melo EP, Martins LO (2008a) Copper incorporation into recombinant CotA laccase from Bacillus subtilis: characterization of fully copper loaded enzymes. J Biol Inorg Chem 13(2):183-193. doi:10.1007/ s00775-007-0312-0

Durao P, Chen ZJ, Silva CS, Soares CM, Pereira MM, Todorovic S, Hildebrandt P, Bento I, Lindley PF, Martins LO (2008b) Proximal mutations at the type 1 copper site of CotA laccase: spectroscopic, redox, kinetic and structural characterization of I494A and L386A mutants. Biochem J 412:339-346. doi:10.1042/Bj20080166

Dwivedi UN, Singh P, Pandey VP, Kumar A (2011) Structure-function relationship among bacterial, fungal and plant laccases. J Mol Catal B Enzym 68(2):117-128. doi:10.1016/j.molcatb.2010.11.002

Endo K, Hayashi Y, Hibi T, Hosono K, Beppu T, Ueda K (2003) Enzymological characterization of EpoA, a laccase-like phenol oxidase produced by Streptomyces griseus. J Biochem 133(5):671-677

Fernandes AT, Soares CM, Pereira MM, Huber R, Grass G, Martins LO (2007) A robust metallo-oxidase from the hyperthermophilic bacterium Aquifex aeolicus. FEBS J 274(11):2683-2694. doi:10.1111/j.1742-4658.2007.05803.x

Givaudan A, Effosse A, Faure D, Potier P, Bouillant ML, Bally R (1993) Polyphenol oxidase in Azospirillum lipoferum isolated from rice rhizosphere-evidence for laccase activity in nonmotile strains of Azospirillum lipoferum. FEMS Microbiol Lett 108(2):205-210. doi:10.1016/0378-1097(93)90586-Q

Grey BN, Steck TR (2001) Concentrations of copper thought to be toxic to Escherichia coli can induce the viable but nonculturable condition. Appl Environ Microbiol 67(11):5325-5327. doi:10.1128/ Aem.67.11.5325-5327.2001

Guan ZB, Zhang N, Song CM, Zhou W, Zhou LX, Zhao H, Xu CW, Cai YJ, Liao XR (2014) Molecular cloning, characterization, and dye-decolorizing ability of a temperature- and $\mathrm{pH}$-stable laccase from Bacillus subtilis X1. Appl Biochem Biotechnol 172(3):1147-1157. doi:10.1007/s12010-013-0614-3

Gunne M, Urlacher VB (2012) Characterization of the alkaline laccase SsI from Streptomyces sviceus with unusual properties discovered by genome mining. PLoS ONE 7(12):e52360. doi:10.1371/journal.pone.0052360

Gunne M, Al-Sultani D, Urlacher VB (2013) Enhancement of copper content and specific activity of CotA laccase from Bacillus licheniformis by coexpression with CopZ copper chaperone in E. coli. J Biotechnol 168(3):252255. doi:10.1016/j.jbiotec.2013.06.011

Gutierrez A, Rencoret J, Cadena EM, Rico A, Barth D, del Rio JC, Martinez AT (2012) Demonstration of laccase-based removal of lignin from wood and non-wood plant feedstocks. Bioresour Technol 119:114-122. doi:10.1016/j.biortech.2012.05.112

Guzik U, Hupert-Kocurek K, Wojcieszynska D (2014) Immobilization as a strategy for improving enzyme properties-application to oxidoreductases. Molecules 19(7):8995-9018. doi:10.3390/molecules19078995

Ihssen J, Reiss R, Luchsinger R, Thöny-Meyer L, Richter M (2015) Biochemical properties and yields of diverse bacterial laccase-like multicopper oxidases expressed in Escherichia coli. Sci Rep 5:10465. doi:10.1038/ srep 10465

Klein-Marcuschamer D, Oleskowicz-Popiel P, Simmons BA, Blanch HW (2012) The challenge of enzyme cost in the production of lignocellulosic biofuels. Biotechnol Bioeng 109(4):1083-1087. doi:10.1002/bit.24370

Koschorreck K, Richter SM, Ene AB, Roduner E, Schmid RD, Urlacher VB (2008) Cloning and characterization of a new laccase from Bacillus licheniformis catalyzing dimerization of phenolic acids. Appl Microbiol Biotechnol 79(2):217-224. doi:10.1007/s00253-008-1417-2

Kumar W, Sivanesan S, Cabana H (2014) Magnetic cross-linked laccase aggregates-bioremediation tool for decolorization of distinct classes of recalcitrant dyes. Sci Total Environ 487:830-839. doi:10.1016/j. scitotenv.2014.04.009

Laemmli UK (1970) Cleavage of structural proteins during the assembly of the head of bacteriophage T4. Nature 227(5259):680-685

Lopez-Gallego F, Betancor L, Hidalgo A, Alonso N, Fernandez-Lafuente R, Guisan JM (2005) Co-aggregation of enzymes and polyethyleneimine: a simple method to prepare stable and immobilized derivatives of glutaryl acylase. Biomacromol 6(4):1839-1842. doi:10.1021/bm050088e

Luis P, Walther G, Kellner H, Martin F, Buscot F (2004) Diversity of laccase genes from basidiomycetes in a forest soil. Soil Biol Biochem 36(7):1025-1036. doi:10.1016/j.soilbio.2004.02.017

Machczynski MC, Vijgenboom E, Samyn B, Canters GW (2004) Characterization of SLAC: a small laccase from Streptomyces coelicolor with unprecedented activity. Protein Sci 13(9):2388-2397. doi:10.1110/ps.04759104

Majumdar S, Lukk T, Solbiati JO, Bauer S, Nair SK, Cronan JE, Gerlt JA (2014) Roles of small laccases from Streptomyces in lignin degradation. Biochemistry 53(24):4047-4058. doi:10.1021/bi500285t

Margot J, Bennati-Granier C, Maillard J, Blanquez P, Barry DA, Holliger C (2013) Bacterial versus fungal laccase: potential for micropollutant degradation. AMB Express 3(1):63. doi:10.1186/2191-0855-3-63

Martins LO, Soares CM, Pereira MM, Teixeira M, Costa T, Jones GH, Henriques AO (2002) Molecular and biochemical characterization of a highly stable bacterial laccase that occurs as a structural component of the Bacillus subtilis endospore coat. J Biol Chem 277(21):18849-18859. doi:10.1074/jbc M200827200

Miyazaki K (2005) A hyperthermophilic laccase from Thermus thermophilus HB27. Extremophiles 9(6):415-425. doi:10.1007/s00792-005-0458-z

Molina-Guijarro JM, Perez J, Munoz-Dorado J, Guillen F, Moya R, Hernandez M, Arias ME (2009) Detoxification of azo dyes by a novel pH-versatile, saltresistant laccase from Streptomyces ipomoea. Int Microbiol 12(1):13-21

Morozova OV, Shumakovich GP, Shleev SV, Yaropolov YI (2007) Laccase-mediator systems and their applications: a review. Appl Biochem Microbiol 43(5):523-535. doi:10.1134/S0003683807050055

Munk L, Sitarz AK, Kalyani DC, Mikkelsen JD, Meyer AS (2015) Can laccases catalyze bond cleavage in lignin? Biotechnol Adv 33(1):13-24. doi:10.1016/j. biotechadv.2014.12.008

Niladevi KN, Jacob N, Prema P (2008) Evidence for a halotolerant-alkaline laccase in Streptomyces psammoticus: purification and characterization. Process Biochem 43(6):654-660. doi:10.1016/j.procbio.2008.02.002

Osipov EM, Polyakov KM, Tikhonova TV, Kittl R, Dorovatovskii PV, Shleev SV, Popov VO, Ludwig R (2015) Incorporation of copper ions into crystals of T2 copper-depleted laccase from Botrytis aclada. Acta Crystallogr F Struct Biol Commun 71:1465-1469. doi:10.1107/S2053230x1502052x

Pereira L, Coelho AV, Viegas CA, Santos MM, Robalo MP, Martins LO (2009) Enzymatic biotransformation of the azo dye Sudan Orange $G$ with bacterial CotA-laccase. J Biotechnol 139(1):68-77. doi:10.1016/j. jbiotec.2008.09.001

Piscitelli A, Pezzella C, Giardina P, Faraco V, Giovanni S (2010) Heterologous laccase production and its role in industrial applications. Bioeng Bugs 1(4):252-262. doi:10.4161/bbug.1.4.11438

Pometto AL, Crawford DL (1986) Effects of $\mathrm{pH}$ on lignin and cellulose degradation by Streptomyces viridosporus. Appl Environ Microbiol 52(2):246-250

Pozdnyakova I, Wittung-Stafshede P (2001) Biological relevance of metal binding before protein folding. J Am Chem Soc 123(41):10135-10136. doi:10.1021/ja016252x

Qiu W, Chen H (2012) Enhanced the enzymatic hydrolysis efficiency of wheat straw after combined steam explosion and laccase pretreatment. Bioresour Technol 118:8-12. doi:10.1016/j.biortech.2012.05.033

Reiss R, Ihssen J, Thöny-Meyer L (2011) Bacillus pumilus laccase: a heat stable enzyme with a wide substrate spectrum. BMC Biotechnol 11(1):9. doi:10.1186/1472-6750-11-9

Robinson PK (2015) Enzymes: principles and biotechnological applications. Essays Biochem 59:1-41. doi:10.1042/Bse0590001

Rodriguez Couto S, Toca Herrera JL (2006) Industrial and biotechnological applications of laccases: a review. Biotechnol Adv 24(5):500-513. doi:10.1016/.j.biotechadv.2006.04.003

Roth S, Spiess AC (2015) Laccases for biorefinery applications: a critical review on challenges and perspectives. Bioprocess Biosyst Eng 38(12):22852313. doi:10.1007/s00449-015-1475-7 
Ruijssenaars HJ, Hartmans S (2004) A cloned Bacillus halodurans multicopper oxidase exhibiting alkaline laccase activity. Appl Microbiol Biotechnol 65(2):177-182. doi:10.1007/s00253-004-1571-0

Sanchez-Amat A, Lucas-Elio P, Fernandez E, Garcia-Borron JC, Solano F (2001) Molecular cloning and functional characterization of a unique multipotent polyphenol oxidase from Marinomonas mediterranea. Biochim Biophys Acta 1547(1):104-116

Sherif M, Waung D, Korbeci B, Mavisakalyan V, Flick R, Brown G, Abou-Zaid M, Yakunin AF, Master ER (2013) Biochemical studies of the multicopper oxidase (small laccase) from Streptomyces coelicolor using bioactive phytochemicals and site-directed mutagenesis. Microb Biotechnol 6(5):588-597. doi:10.1111/1751-7915.12068

Si W, Wu Z, Wang L, Yang M, Zhao X (2015) Enzymological characterization of Atm, the first laccase from Agrobacterium sp. S5-1, with the ability to enhance in vitro digestibility of maize straw. PLoS ONE 10(5):e0128204. doi:10.1371/journal.pone.0128204

Sinirlioğlu ZA, Sinirlioğlu D, Akbas F (2013) Preparation and characterization of stable cross-linked enzyme aggregates of novel laccase enzyme from Shewanella putrefaciens and using malachite green decolorization. Bioresour Technol 146:807-811. doi:10.1016/j.biortech.2013.08.032
Suzuki T, Endo K, Ito M, Tsujibo H, Miyamoto K, Inamori Y (2003) A thermostable laccase from Streptomyces lavendulae REN-7: purification, characterization, nucleotide sequence, and expression. Biosci Biotechnol Biochem 67(10):2167-2175. doi:10.1271/bbb.67.2167

Thurston CF (1994) The structure and function of fungal laccases. Microbiology 140:19-26

Tonin F, Melis R, Cordes A, Sanchez-Amat A, Pollegioni L, Rosini E (2016) Comparison of different microbial laccases as tools for industrial uses. New Biotechnol 33(3):387-398. doi:10.1016/j.nbt.2016.01.007

Widsten P, Kandelbauer A (2008) Laccase applications in the forest products industry: a review. Enzyme Microb Technol 42(4):293-307. doi:10.1016/j. enzmictec.2007.12.003

Zhang XY, Tan J, Wei XH, Wang LJ (2013) Removal of Remazol turqoise blue G-133 from aqueous solution using modified waste newspaper fiber. Carbohydr Polym 92(2):1497-1502

\section{Submit your manuscript to a SpringerOpen ${ }^{\circ}$ journal and benefit from:}

- Convenient online submission

- Rigorous peer review

- Immediate publication on acceptance

- Open access: articles freely available online

- High visibility within the field

- Retaining the copyright to your article 